\title{
The Influence of Light Intensity on Anatomical Structure and Pigment Contents of Tradescantia pallida (Rose) Hunt. cv. purpurea Boom (Commelinaceae) Leaves
}

\author{
Élder Antonio Sousa Paiva, Rosy Mary dos Santos Isaias", Fernando Henrique Aguiar Vale \\ and Cristina Generosa de Senna Queiroz \\ Universidade Federal de Minas Gerais; Instituto de Ciências Biológicas; Departamento de Botânica; Av. Antonio \\ Carlos, 6627; 31270-901; Belo Horizonte - MG - Brazil
}

\begin{abstract}
The aim of this work was to study the effects of five different light intensities on the anatomical structure and on the pigment contents in leaves of Tradescantia pallida $c v$. purpurea. Once light intensity became lower, the thickness of leaf lamina and mesophyll were reduced. Adjustments in light-harvesting antenna size were observed: an increase in chlorophyll $a+b /$ carotenoids ratio at low-light growth conditions. There was a strong positive linear correlation between the light intensity values and anthocyanin contents. Hence, T. pallida $c v$. purpurea acclimation to distinct environmental conditions might be related to its capacity of altering structurally and physiologically its phenotype.
\end{abstract}

Key words: Leaf anatomy; light intensity; chlorophyll; carotenoids; anthocyanin; Tradescantia

\section{INTRODUCTION}

Comparative studies on the leaf structure have demonstrated that the majority of plant species have the ability to develop anatomically distinct leaves in response to different light intensities (Vogelmann and Martin 1993; StraussDebenedetti and Berlyn 1994). Thus, light intensity promotes alterations in the structural organization of the leaves, resulting in what has been called leaves of sun and shade (Cutter 1978). According to Clough et al. (1979), light is the environmental variable, which most influences phenotypes and that the process of acclimation to different light levels is highly correlated with changes in leaf mass per unit area. Leaves exposed to high light intensities, generally present an increase in the number of cell layers in palisade parenchyma, and consequently in mesophyll thickness (Kubínová 1991). This was reinforced by Buisson and Lee (1993), with Carica papaya, where the leaves of plants kept under shade conditions were thinner and with reduced specific leaf mass in comparison to those kept under sunny conditions.

Plants of Alocasia macrorrhiza kept under low light intensities were transferred to higher light intensities. Mature leaves did not alter while not expanded leaves became thicker (Sims and Pearcy 1992). According to Adamson et al. (1991), leaf development of Tradescantia albiflora was seriously influenced by the light. Leaves produced under high luminosity were reduced in size, thicker and presented a low chlorophyll content than leaves produced in moderate shade. Also, in full sunlight, $T$. albiflora presented the ability to

\footnotetext{
* Author for correspondence
} 
reduce its light-harvesting potential, which is a feature of most shade plants.

Tradescantia colonize a wide range of environments, since those completely exposed to sun light up to those deeply shady. This feature makes this genus serious weed invader (LeitãoFilho et al. 1982), which has been causing problems to the agriculture in Minas Gerais state (Brandão et al. 1985). Their strategy and efficiency as weed invaders are probably directly associated to their adaptation to distinct light intensities.

The knowledge about anatomical structures is a relatively easy way of studying and comprehending partially the evolutive strategies, which permit the species of this genus to be efficient in the invasion of plant crops. The comprehension of these strategies may help in the formulation of proposals of controlling and manipulating these species, with reduced damages to environment. This research shows the effects of different light intensities on the anatomical structure and in the pigment contents in the leaves of Tradescantia pallida.

\section{MATERIAL AND METHODS}

Tradescantia pallida cv. purpurea (Rose) Hunt. plants were vegetatively propagated from one unique plant and cultivated under five different levels of light intensity. The treatments were: (1) $100 \%$ of daily average radiation (DAR); (2) 50\% of DAR; (3) $25 \%$ of DAR; (4) $10 \%$ of DAR and (5) $5 \%$ of DAR. The different light intensities were obtained with shade cloth. The daily average radiation during experimental period was 800 $\mu \mathrm{mol} . \mathrm{m}^{-2} \cdot \mathrm{s}^{-1}$ for the plants maintained at treatment 1. The plants were maintained in the experimental conditions up to the expansion of the tenth leaves for about 4 months. The leaves were collected and submitted to the anatomical and pigment contents analysis.

\section{Scanning electron microscopy}

Tissues from leaves submitted to $800 \mu \mathrm{mol} . \mathrm{m}^{-2} . \mathrm{s}^{-1}$ and $40 \mu \mathrm{mol} \cdot \mathrm{m}^{-2} \cdot \mathrm{s}^{-1}$ were collected, washed in distilled water and placed between two sheets of filter paper for 7 days in a desiccator with silica gel, afterwards they were transferred to an oven at $40^{\circ} \mathrm{C}$. When the leaves were completely dry, $0.5 \mathrm{~cm}^{2}$ fragments of the medium region were cut and glued to the stubs. The fragments were covered with gold, at $15 \mathrm{mV}$ for $40 \mathrm{~s}$ in Balzers BAF-300 model BSV 203.

\section{Light microscopy and histochemical analyzes}

The anatomical studies were performed in the eighth and tenth leaves of each treatment, which were fixed in $\mathrm{FAA}_{50}$ (Gahan 1984), dehydrated and infiltrated in Paraplast ${ }^{\circledR}$ (Kraus and Arduin 1997) and in historesin Technovit ${ }^{\circledR}$ (following the product recommendations). Transverse sections $(12 \mu \mathrm{m})$ were obtained in a rotative microtome, and submitted to staining in Toluidine Blue $\mathrm{O}$ (O'Brien and McCully 1981). Freehand sections were performed in order to help anatomical description and histochemical analyses. Epidermal fragments were peeled off from the medium regions of the leaves. Stomatal indexes were calculated according to (Cutter 1978), by using the following formula:

$$
\text { S.I. }=\frac{\mathrm{n}^{\circ} \text { stomata }}{\mathrm{n}^{\circ} \text { stomata }+\mathrm{n}^{\circ} \text { epidermal cells }}
$$

\section{Determination of leaf pigment contents}

Chlorophyll and carotenoids contents were determined in acetone extracts (Lichtenthaler and Wellburn 1983), while anthocyanin levels were estimated from methanolic extracts as: $\mathrm{A}_{\text {ant }}=\left(\mathrm{A}_{530}\right.$ - $\left.A_{620}\right)-0,1\left(A_{650}-A_{620}\right)$ (Creasy 1968). The corrected absorbance was converted in mol of anthocyanin using the extinction coefficient of $\xi=34300 \mathrm{mmol}^{-1} \mathrm{~cm}^{-1}$ for the maximum absorbance at 530nm (Sielgelman and Hendricks 1958).

\section{RESULTS AND DISCUSSION}

\section{Anatomical structure}

The epidermal cells of the plants submitted to the five distinct light intensities were of similar size and without chloroplasts. Colorless hypodermal cells were observed just beneath the epidermal cells on the adaxial side of leaf lamina. These cells were similar to those described by Tomlinson (1969), presented anticlinal walls frequently wrinkled in transverse section (Fig. 2) and their presence was usually related to water-storage (Solereder and Meyer 1929). In T. pallida, hypodermal cells were very large, responsible for the majority of the thickness of leaf lamina. In plants submitted to light intensities of $800 \mu \mathrm{mol} . \mathrm{m}^{-}$ ${ }^{2} \cdot \mathrm{s}^{-1}, \quad 400 \mu \mathrm{mol} \cdot \mathrm{m}^{-2} \cdot \mathrm{s}^{-1}$ and $200 \mu \mathrm{mol} \cdot \mathrm{m}^{-2} \cdot \mathrm{s}^{-1}$, this 
tissue was constituted of 2-3 cell layers, whereas in plants submitted to $80 \mu \mathrm{mol} \cdot \mathrm{m}^{-2} \cdot \mathrm{s}^{-1}$ and $40 \mu$ mol. $\mathrm{m}^{-2} \cdot \mathrm{s}^{-1}$, the hypodermis tended to be reduced to 1-2 cell layers. The size of hypodermal cells was also reduced in the latter two light intensities (Fig. 4-5).

It could be that, the hypodermis together with the epidermis were functioning in focusing, and concentrating light. As is already known, epidermal cells' focusing facilitates the penetration of light into leaves, and they appear to concentrate light (Vogelmann and Martin 1993). The epidermis on the adaxial surface was also constituted of large cells, with thin cell walls, and without trichomes.
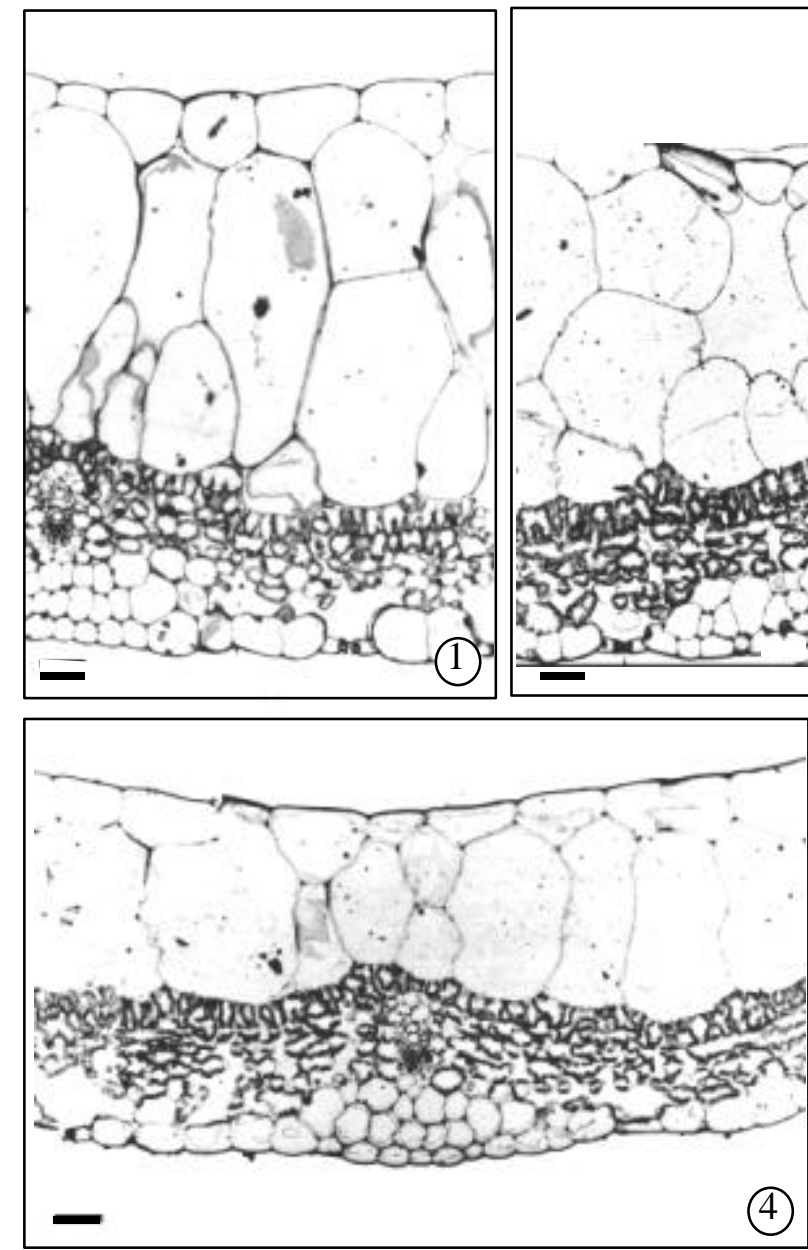
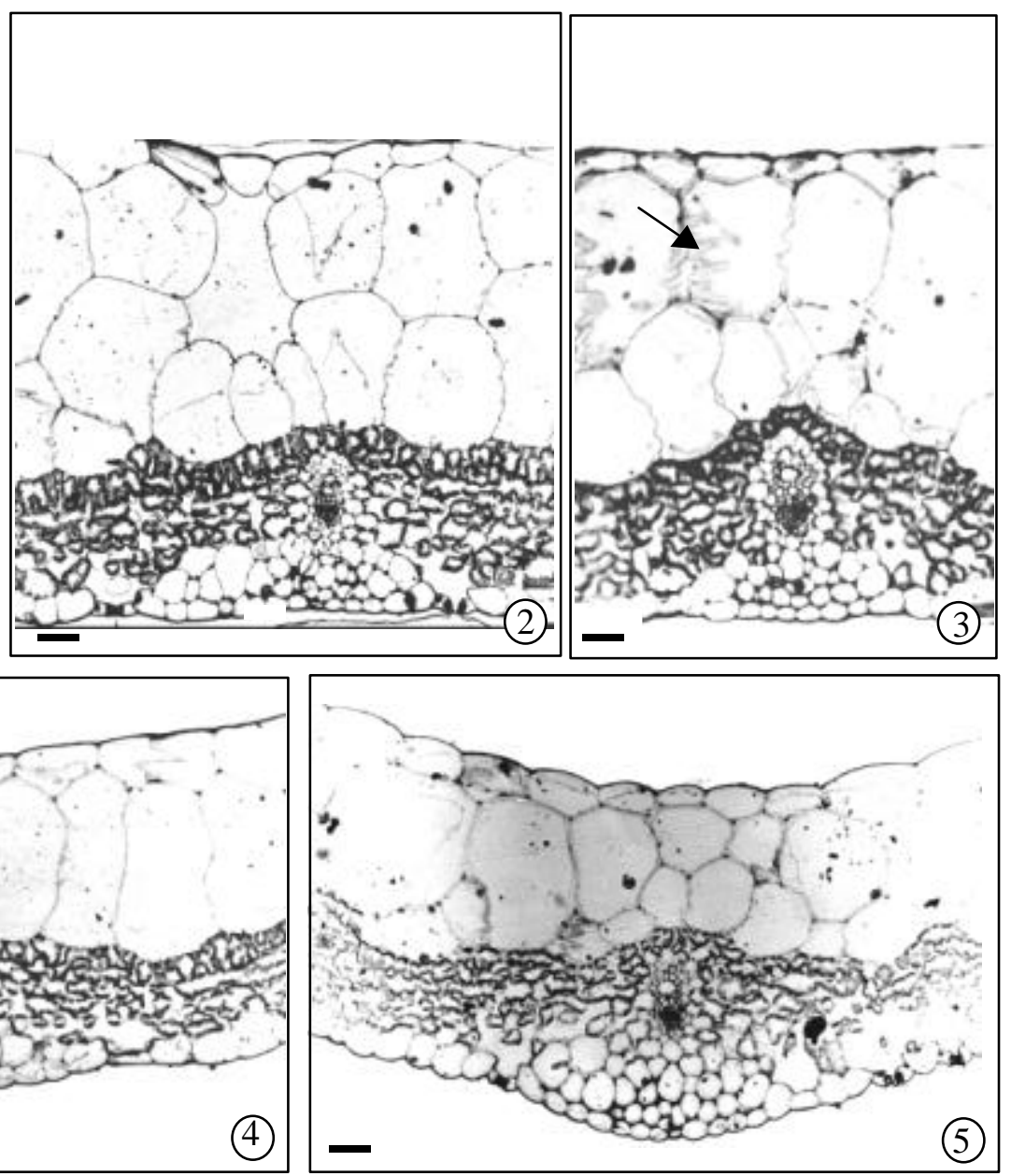

Figures 1-5 - Tradescantia pallida cv. purpurea leaves submitted to distinct light intensities. (1) $100 \%$ (800 $\left.\mu \mathrm{mol} \cdot \mathrm{m}^{-2} \cdot \mathrm{s}^{-1}\right)$. Hypodermis represents more than $50 \%$ of leaf thickness. Mesophyll is dorsiventral. (2) $50 \%$ $\left(400 \mu \mathrm{mol} \cdot \mathrm{m}^{-2} \cdot \mathrm{s}^{-1}\right)$. Hypodermal cells are slightly reduced in size. (3) $25 \%\left(200 \mu \mathrm{mol} \cdot \mathrm{m}^{-2} \cdot \mathrm{s}^{-1}\right)$. Leaf lamina is reduced in thickness. Anticlinal cell walls are plicated (arrow). (4) $10 \%\left(80 \mu \mathrm{mol} \cdot \mathrm{m}^{-2} \cdot \mathrm{s}^{-1}\right)$. Hypodermis is constituted of onecell layer. Leaf lamina thickness is reduced. (5) $5 \%\left(40 \mu \mathrm{mol} \cdot \mathrm{m}^{-2} \cdot \mathrm{s}^{-1}\right)$. Hypodermal cells are reduced in size. Palisade tissue is completely undifferentiated. (Bars $=50 \mu \mathrm{m})$.

The treatments did not alter these features, but altered the epicuticular wax on this leaf surface (Fig. 6-7). The variations in epicuticular layers thickening were clear responses to environmental variations, especially light intensities, and were generally registered as xeromorphic features (Mauseth 1988; Fahn 1990).
The cells of epidermis on the abaxial surface presented reduced volume, when compared to the adaxial surface, its anticlinal walls were straight and they were polygonal in shape when observed in frontal view. Tetracitic stomata (Wilkinson, 1983) were distributed all over the lamina, except on the vein regions. 
Cutter (1978) stated that the stomatal index was constant for any particular species, and so was true for the plants of T. pallida cv. purpurea studied. Nevertheless, the same author affirmed that humidity variations and low light intensities might induce alterations in formation of stomata, which was not actually observed.

Croxdale (1998) discussed various ways in which stomatal patterning might be formed in monocotyledons, using Tradescantia as a model system. According to Glover (2000), signaling between differentiating cells was more important than cell lineage in plant cell patterning. According to Croxdale (1998), stomatal patterning occurred relatively late in Tradescantia leaf development, and patterning and differentiation of epidermal cells might take place even later. For actual observations, there was no evidence that different light intensities should have activated the complex set of signals described by Glover (2000), and necessary for altering epidermal cell patterning.

The mesophyll of $T$. pallida cv. purpurea was dorsiventral, with small, irregular cells where chloroplasts were numerous. It represented just a small portion of the total volume of leaf tissue. Palisade was constituted of one cell layer and spongy parenchyma was 4-5 cell layered (Fig. 1). All the five distinct light intensities altered the thickness of mesophyll tissues (Figs. 1-5). Three groups were observed: the first constituted of plants submitted to light intensities of $800 \mu$ mol.m ${ }^{2} \cdot \mathrm{s}^{-1}$ and $400 \mu \mathrm{mol} \cdot \mathrm{m}^{-2} \cdot \mathrm{s}^{-1}$; another one constituted of plants submitted to $200 \mu \mathrm{mol} . \mathrm{m}^{-2} \cdot \mathrm{s}^{-1}$ and the last constituted of plants submitted to $80 \mu \mathrm{mol} \cdot \mathrm{m}^{-2} \cdot \mathrm{s}^{-1}$ and $40 \mu \mathrm{mol} \cdot \mathrm{m}^{-2} \cdot \mathrm{s}^{-1}$ (Table 1). These alteration might be clearly attributed to gradual inhibition of palisade tissue differentiation, which was more evident in leaves submitted to

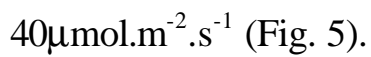

Palisade thickness is a good predictor of maximum photosynthetic rate, but only on a species-specific basis. Overall, leaf thickening with increasing irradiance was associated with structural and photosynthetic changes (StraussDebenedetti and Berlyn 1994). Columnar palisade cells facilitated more equal distribution of light to chloroplasts within the leaf, for it facilitated the penetration of the direct light components. By allowing light to penetrate deeper into thicker leaves, it was possible to distribute light more uniformly to chloroplasts within the leaf (Vogelmann and Martin 1993).

The packaging of chlorophyll in chloroplasts resulted in shading between the chlorophyll molecules and created gaps between chloroplasts, where light was not absorbed, referred to as sieve effect (Taiz and Zeiger 1998). Light channeling occurred when some of the incident light was propagated through the central vacuole of the palisade cells and through air spaces between the cells, and arrangement that facilitated the transmission of light into the leaf interior (Vogelmann and Martin 1993).

The irregular shape and large air spaces of spongy mesophyll cells reflect and refract light, randomizing its direction of travel, a phenomenon called light scattering which should favor T. pallida cv. purpurea leaves submitted to $40 \mu \mathrm{mol} . \mathrm{m}^{-2} \cdot \mathrm{s}^{-1}$.

Table 1 - Effect of light intensity on mesophyll and leaf lamina thickness and stomatal index (\%) in the leaves of $T$. pallida.

\begin{tabular}{cccc}
\hline $\begin{array}{c}\text { Light intensity } \\
\left(\boldsymbol{\mu} \text { mol.m } \mathbf{m}^{-\mathbf{2}} \mathbf{s}^{-\mathbf{1}}\right)\end{array}$ & $\begin{array}{c}\text { Lamina } \\
(\boldsymbol{\mu} \mathbf{m})\end{array}$ & $\begin{array}{c}\text { Mesophyll } \\
(\boldsymbol{\mu} \mathbf{m})\end{array}$ & Stomatal Index \\
\hline 800 & $1015 \mathrm{a}$ & $265 \mathrm{a}$ & $17,0 \mathrm{a}$ \\
400 & $983 \mathrm{a}$ & $240 \mathrm{a}$ & $18,1 \mathrm{a}$ \\
200 & $825 \mathrm{~b}$ & $193 \mathrm{~b}$ & $17,1 \mathrm{a}$ \\
80 & $595 \mathrm{c}$ & $145 \mathrm{c}$ & $17,0 \mathrm{a}$ \\
40 & $440 \mathrm{~d}$ & $130 \mathrm{c}$ & $18,9 \mathrm{a}$ \\
\hline
\end{tabular}

The average values followed by the same letter, in the same column, do not differ at $5 \%$ level of probability in the Tukey test. 
The thickness of leaf laminas in plants of $T$. pallida cv. purpurea submitted to light intensities of $800 \mu \mathrm{mol} \cdot \mathrm{m}^{-2} \cdot \mathrm{s}^{-1}$ and $400 \mu \mathrm{mol} \cdot \mathrm{m}^{-2} \cdot \mathrm{s}^{-1}$ did not differ, while plants submitted to $200 \mu \mathrm{mol} \cdot \mathrm{m}^{-2} \cdot \mathrm{s}^{-1}$ to $40 \mu \mathrm{mol} \cdot \mathrm{m}^{-2} \cdot \mathrm{s}^{-1}$ presented thinner lamina (Table 1). These alterations might be due to the reduction in hypodermal cells size (Fig. 1-5). Haberlandt (1928) had already described the increase in leaf thickness due to enlargement of water tissue in a species of Rhizophora.

Clough et al. (1979) reported that changes in light level influenced photosynthesis and growth of definite plants more than changes in water availability or temperature. Therefore, the primary adaptive response they found in tested individuals of Solanum dulcamara, to changes in levels of light, involved the regulation of leaf thickness, and so was true for T. pallida cv. purpurea leaves.

\section{Scanning Electron Microscopy}

The epicuticular wax on the epidermis of $T$. pallida cv. purpurea were deposited in the shape of plates disposed perpendicular to the epidermal surface. The density of the wax plates was higher in leaves of plants submitted to high light intensities $\left(800 \mu \mathrm{mol} . \mathrm{m}^{-2} \cdot \mathrm{s}^{-1}\right)$ (Fig. 6) than in the leaves of plants submitted to low light intensities $\left(40 \mu \mathrm{mol} \cdot \mathrm{m}^{-2} \cdot \mathrm{s}^{-1}\right)$ (Fig. 7). According to Welker and Furuya (1994), the action of the epicuticular wax in limiting the evapotranspiration was a product of the architecture of the deposits and of the quantity of wax per unit of area. Even though, the deposits of epicuticular wax in T. pallida cv. purpurea epidermis were not quantified, the alterations were visually clear.

The epicuticular wax layer of $T$. pallida cv. purpurea was uniform except near the guard-cells of the stomata, where the plates were less numerous. A similar result was obtained for Upadhyaya and Furness (1994) in Tragopogon dubius and T. pratensis. Conspicuous differences in epicuticular wax features were not observed between the adaxial and the abaxial surface of $T$. pallida cv. purpurea epidermis.
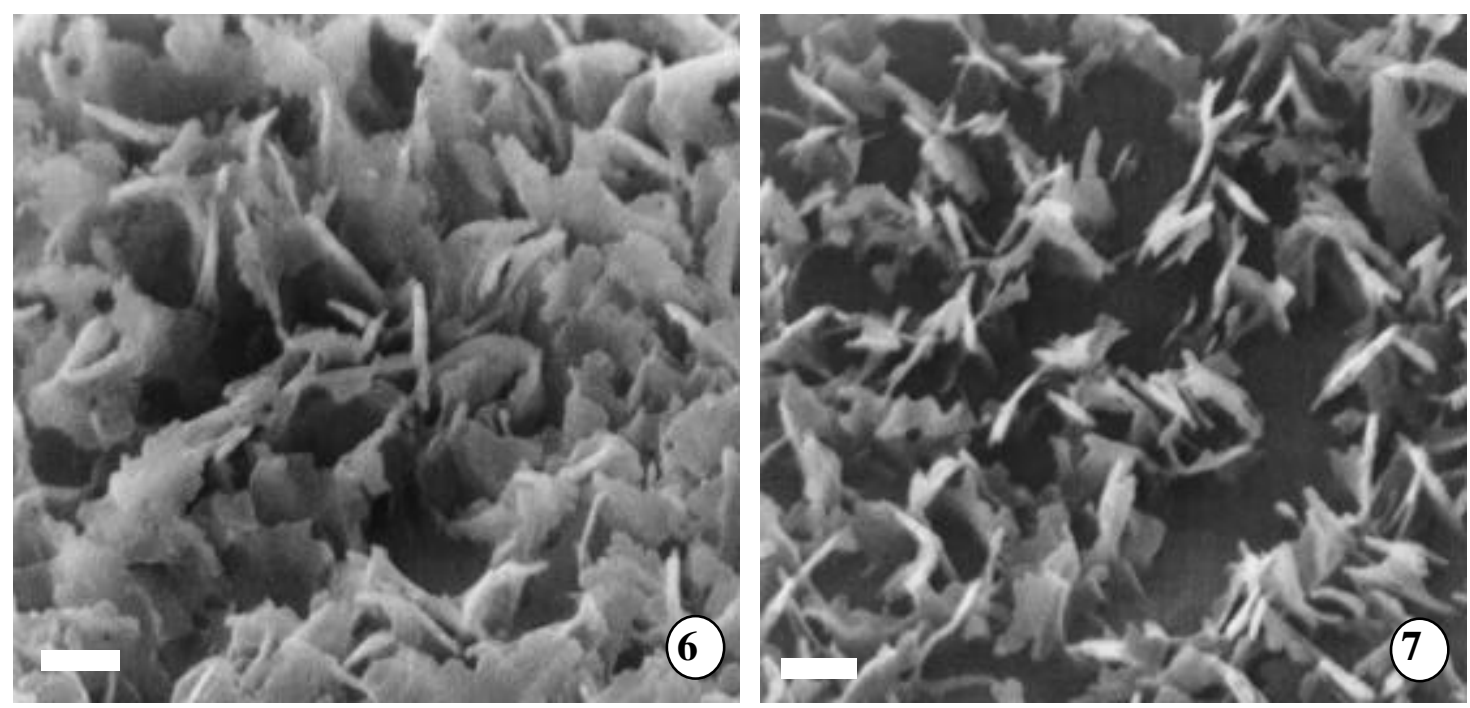

Figure 6-7 - Epicuticular wax on Tradescantia pallida cv. purpurea epidermis as seen in Scanning Electron Microscopy. (6) Adaxial epidermal surface of leaves submitted to $800 \mu \mathrm{mol} \cdot \mathrm{m}^{-2} \cdot \mathrm{s}^{-1}$. (7) Adaxial surface of leaves submitted to $40 \mu \mathrm{mol} \cdot \mathrm{m}^{-2} \cdot \mathrm{s}^{-1}$. (Bars $\left.=1 \mu \mathrm{m}\right)$.

\section{Pigment contents and dry mass}

The percentage of leaf dry mass in T. pallida cv. purpurea leaves gradually decreased (Table 2) with the reduction of light intensity. Otherwise, the specific leaf area increased in the same conditions. When the plants cultivated under high light intensities were compared to those cultivated under low light intensities, it was possible to verify 
that the first presented almost the double of dry mass, which corresponded to the most reduced values of specific leaf area. This inversion was related to the typical structure of shade leaves that T. pallida $\mathrm{cv}$. purpurea plants assumed under low light intensities, i.e., thin leaf thickness (Table 1), with undifferentiated mesophyll and thick epidermal and hypodermal layers.

The reduction in light intensities did not induce a variation in chlorophyll contents and in chlorophyll $a / b$ ratio (Table 2). Nevertheless, at low-light growth conditions, and in the shade, a higher ratio chlorophyll $a+b /$ carotenoids might be found (Lichtenthaler, 1987), what could be demonstrated in T. pallida. As reported previously (Adamson et. al. 1991), the Chl alb ratios of Tradescantia plants grown over a wide range of light intensities were also constant. Light intensities from $200 \mu \mathrm{mol} . \mathrm{m}^{-2} . \mathrm{s}^{-1}$ to $800 \mu \mathrm{mol} . \mathrm{m}^{-}$ ${ }^{2} \cdot \mathrm{s}^{-1}$ promoted higher levels of carotenois in $T$. pallida cv. purpurea (Table 2). These pigments have been associated to the protection of the photosynthetic apparatus against the actions of oxygen free radicals (Krause, 1988), whose production increases under high light intensities.

Table 2. Effect of light intensity in percentage of leaf dry mass, specific leaf area, pigment contents, chlorophyll $a /$ chlorophyll $b$ ratio, carotenoids/chlorophyll ratio, in Tradescantia pallida cv. purpurea leaves.

\begin{tabular}{|c|c|c|c|c|c|c|c|c|}
\hline $\begin{array}{c}\text { Light } \\
\text { intensity } \\
\left(\mu \mathrm{mol} . \mathrm{m}^{-2} \cdot \mathrm{s}^{-1}\right)\end{array}$ & $\begin{array}{c}\text { Dry mass } \\
(\%)\end{array}$ & $\begin{array}{c}\text { Specific leaf area } \\
\left(\mathrm{m}^{2} \cdot \mathrm{Kg}^{-1} \mathrm{DW}\right)\end{array}$ & $\begin{array}{l}\text { Chlor. a } \\
\left(\mu g . \mathrm{cm}^{-2}\right)\end{array}$ & $\begin{array}{l}\text { Chlor. b } \\
\left(\mu g . \mathrm{cm}^{-2}\right)\end{array}$ & $\begin{array}{c}\text { Chlor. } \\
\text { a/b }\end{array}$ & $\begin{array}{c}\text { Carot. } \\
\left(\mu \mathrm{g.cm}^{-2}\right)\end{array}$ & $\begin{array}{l}\text { Chlor./ } \\
\text { Carot. }\end{array}$ & $\begin{array}{c}\text { Anthocyan. } \\
\left(\mu \text { g.cm }^{-2}\right)\end{array}$ \\
\hline 800 & $5.525 \mathrm{a}$ & $19,0 \mathrm{~d}$ & $18.50 \mathrm{a}$ & $12.51 \mathrm{a}$ & $1.478 \mathrm{a}$ & $1.25 \mathrm{ab}$ & $24.800 \mathrm{~b}$ & $13.07 \mathrm{a}$ \\
\hline 400 & $5.315 \mathrm{a}$ & $20,4 \mathrm{~cd}$ & $16.92 \mathrm{a}$ & $07.77 \mathrm{a}$ & $2.178 \mathrm{a}$ & $1.33 \mathrm{a}$ & $18.563 \mathrm{c}$ & $9.34 \mathrm{~b}$ \\
\hline 200 & $4.818 \mathrm{a}$ & $26,1 \mathrm{c}$ & $17.93 \mathrm{a}$ & $10.31 \mathrm{a}$ & $1.739 \mathrm{a}$ & $1.18 \mathrm{~b}$ & $23.941 \mathrm{bc}$ & $6.22 c$ \\
\hline 80 & $3.748 \mathrm{~b}$ & $42,5 \mathrm{~b}$ & $18.15 \mathrm{a}$ & $09.40 \mathrm{a}$ & $1.931 \mathrm{a}$ & $0.80 \mathrm{c}$ & $34.438 \mathrm{a}$ & $1.69 \mathrm{~d}$ \\
\hline 40 & $3.030 \mathrm{~b}$ & $56,3 \mathrm{a}$ & $15.79 \mathrm{a}$ & $07.16 \mathrm{a}$ & $2.205 \mathrm{a}$ & $0.64 \mathrm{~d}$ & $35.844 \mathrm{a}$ & $0.35 \mathrm{~d}$ \\
\hline
\end{tabular}

The average values followed by the same letter, in the same column, do not differ at $5 \%$ level of probability in the Tukey test.

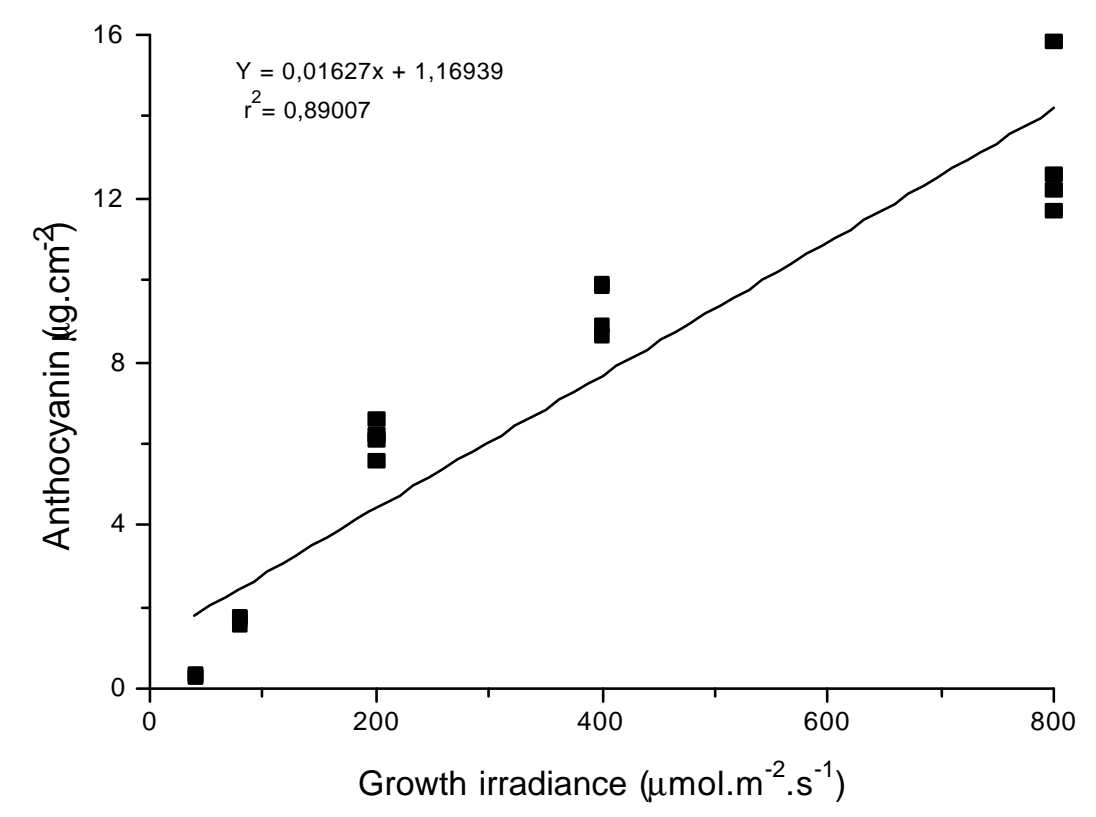

Figure 8 - Correlation between light intensity and anthocyanin levels in Tradescantia pallida cv. purpurea leaves. 
Several researches have demonstrated that light in excess may cause damage to the photosynthetic apparatus and that photosynthetic organisms present a few mechanisms for photoprotection. Within the chloroplast, regulation of photosynthetic light harvesting, and electron transport balances the absorption and utilization of light energy. For example, adjustments in lightharvesting antenna size and photosynthetic capacity can decrease light absorption and increase light utilization, respectively, during relatively long-term acclimation to excessive light (Niyogi, 1999).

The alterations detected in photosynthetic pigments in T. pallida cv. purpurea suggested that the increase in carotenoid levels, under high light irradiance might protect the chloroplasts from photoinhibition, and might permit a higher biomass production under these light conditions. This protection of tilacoid membrane integrity is fundamental to the photosynthetic activity (Siefermann-Harms, 1987, Niyogi, 1999).

Another reason for the acclimation of T. pallida cv. purpurea plants to sunny conditions might be attributed to the higher accumulation of anthocyanins in the leaves, stimulated by an increase in light irradiance (Table 2). There was a strong positive linear correlation $(r=0.89007)$ between the light intensity values and anthocyanin contents (Fig. 8). According to Chalker-Scott (1999), anthocyanins often appear transiently at specific developmental stages and may be induced by visible and UVB radiation, cold temperatures and water stress. Under high flux of photons, an increase in the production of oxygen free radicals associated to photosynthesis may occur. The adaptations to this stress situation depends on the presence of an anti-oxidant system, and there are some recent evidences that anthocyanins may act as free radicals captors, avoiding lipid membranes oxidation (Gabrielska et al., 1999). Therefore, it is probable that these pigments may be acting as photoprotectors of membrane integrity in plants of T. pallida, in response to light radiation, and also may protect these leaves against photoinhibition (Gould et. al. 1995).

\section{General remarks}

Even though $T$. pallida cv. purpurea has been described as an species whose natural habitat may be shady areas (Leitão Filho et al. 1982), present data showed that this species could colonize a wide range of environments. $T$. pallida cv. purpurea acclimation to distinct environmental conditions might be related to its capacity of altering structurally and physiologically its phenotype.

\section{ACKNOWLEDGMENTS}

The authors would like to thank FAPEMIG CBS-948/96 - for financial support.

\section{RESUMO}

As espécies de Tradescantia colonizam uma ampla faixa de ambientes, desde aqueles completamente expostos a luz até aqueles caracteristicamente sombreados. Suas estratégias adaptativas e eficiência como invasoras de culturas estão provavelmente associadas a sua adaptação a intensidades luminosas distintas. Este trabalho mostra os efeitos de cinco diferentes intensidades luminosas na estrutura anatômica e no teor de pigmentos em folhas de Tradescantia pallida. As espessuras da lâmina foliar e do mesofilo foram alteradas, tornando-se mais delgadas à medida que a intensidade luminosa diminuiu. Observou-se um ajuste nos pigmentos fotossintéticos caracterizado por aumentos na razão clorofilas/carotenóides sob condições de baixa intensidade luminosa. Houve uma forte correlação linear positiva entre os valores de intensidade luminosa e teores de antocianinas. Deste modo, pode-se concluir que a aclimatação da espécie aos diferentes habitats está relacionada a alterações estruturais e fotossintéticas.

\section{REFERENCES}

Adamson, H. Y.; Chow, W. S.; Anderson, J. M.; Vesk, M. and Sutherland, M. W. (1991), Photosynthetic acclimation of Tradescantia albiflora to growth irradiance: morphological, ultrastructural and growth responses. Physiol. Plant., 82 : (3), 353-359.

Brandão, M. Laca-Buendia, J. P.; Gavilanes, M. L.; Zurlo, M. A.; Cunha, L. H. S. and Cardos, C. (1985), Novos enfoques para plantas consideradas daninhas. Inf. Agropec., 11 : (129), 3-14.

Buisson, D. and Lee, D. W. (1993), The developmental responses of papaya leaves to simulated canopy shade. Am. J. Botany, 80 : (8), 947-952. 
Chalker-Scott, L. (1999), Environmental significance of anthocyanins in plant stress responses. Photochemistry and Photobiology, 70 : (1), 1-9.

Clough, J. M.; Alberte, R. S. and Teeri, J. A. (1979), Photosynthetic adaptation of Solanum dulcamara L. to sun and shade environments. Plant Physiol., 64, 25-30.

Creasy, L. L. (1968), The role of low temperature in anthocyanin synthesis in McIntosh Apples. Proc. Am. Hort. Sci., 93, 715-724.

Croxdale, J. (1998), Stomatal patterning in monocotyledons: Tradescantia as a model system. Journ. Exp. Bot., 49, 279-292.

Cutter, E. G. (1978), Plant Anatomy: Cells and Tissues Part I, London. William Clowes and Sons, 315p.

Fahn, A. (1990), Plant anatomy. 4. ed. New York : Pergamon Press. 588 pp.

Gabrielska, J. (1999), Anthocyanin extracts with antioxidant and radical scavenging effect. Zeitschrift fur naturforschung $C$-A Journal of Biosciences, 54 : (5-6), 319-324.

Gahan, P. B. (1984), Plant Histochemistry and Citochemistry: an introduction. London : Academic Press. $301 \mathrm{pp}$.

Glover, B. J. (2000), Differentiation in plant epidermal cells. Journ. Exp. Bot., 51, 497-505.

Gould K. S.; Kuhn, D.; Lee, D. and Oberbauer, S. F. (1995), Why leaves are sometimes red, Nature, 378, 241-242.

Haberlandt, G. (1928), Physiological plant anatomy. London : MacMillan and Co. pp. 397-409.

Krause, G. H. (1988), Photoinhibition of photosynthesis. An evaluation of damage and protective mechanisms. Physiol. Plantarum, 74, 566-574.

Kraus, J. E. and Arduin, M. (1997), Manual básico de métodos em morfologia vegetal. Seropédica : Univ. Federal Rural do Rio de Janeiro. 198 pp.

Kubínová, L. (1991), Stomata and mesophyll characteristics of barley leaf as affected by light: Stereological analysis. J. Exp. Botany, 42 : (241), 995-1001.

Lee, D. W.; Bone, R.; Tarsis, S. and Storch, D. (1990), Correlates of leaf optical properties in tropical forest extreme shade and sun plants. Am. J. Botany, 77, 370-380.

Leitão-Filho, H. F.; Aranha, C. and Bacchi, O (1982), Plantas invasoras de culturas. Campinas : Hucitec. $291 \mathrm{pp}$.

Lichtenthaler, H. K.; Wellburn, A. R. (1983), Determination of total carotenoids and chlorophylls a and $b$ of leaf extracts in different solvents. Biochemical Society Transactions, 11, 591-592.

Lichtenthaler, H. K. (1987), Chlorophylls and carotenoids: pigments of photosynthetic biomembranes. Methods in Enzymology, 148, 350-382.

Mauseth, J. (1988), Plant anatomy. The Benjamin Cummings Pub. Comp. Inc. Menlo Park. 560 pp.
Niyogi, K. K. (1999), Photoprotection revisited: genetic and molecular approaches. Ann. Rev. Plant Physiol. Plant Mol. Biol., 50, 333-359.

O'brien, T. P. and McCully, M. E. (1981), The study of plant structure principles and selected methods. Termarcarphi PTX, Mellrime, (Australia).

Sielgelman, H. W. and Hendricks, S. B. (1958), Photocontrol of anthocyanin synthesis in apple skin. Plant Physiol., 33, 185-190.

Siefermann-Harms, D. (1987), The light-harvesting and protective functions of carotenoids in photosynthetic membranes. Physiol. Plantarum, 69, 561-568.

Sims, D. A. and Pearcy, R. W. (1992), Response of leaf anatomy and photosynthetic capacity in Alocasia macrorrhiza to transfer from low to high light. Am. J. Botany, 79 : (4), 449-455.

Solereder, H. and Meyer, F. J. (1929), Commelinaceae in Systematische Anatomie der Monokotyledonen, Helf IV. pp. 129-155.

Strauss-Debenedetti, S. and Berlyn, G. P. (1994), Leaf anatomical responses to light in life tropical Moraceae of different successional status. Am. J. Botany, 81 : (12), 1582-1591.

Taiz, L. and Zeiger, E. (1998), Plant physiology. Second ed. Sinauer Associates, Inc. pp. 227-249.

Tomlinson, P. B. (1969), Anatomy of the Monocotyledons. Oxford : Clarendon Press. v. 3. pp. 12-63.

Upadhyaya, M. K. and Furness, N. H. (1994), Influence of intensity and water stress on leaf surface characteristics of Cynoglossum officinale, Centaurea spp. and Tragopogon spp. Can. J. Botany, 72, 1379-1386.

Vogelmann, T. C. and Martin, G. (1993), The functional significance of palisade tissue: penetration of directional versus diffuse light. Plant, Cell Environ., 16, 65-72.

Welker, O. A. and Furuya, S. (1994), Surface structure of leaves in heat tolerant plants. J. Agron. Crop. Sci., 173 : (3-4), 279-288.

Wilkinson, H. P. (1983), The plant surface (mainly leaf). In: Metcalfe, C. R. and Chalk, L. (ed.). Anatomy of the dicotyledons. Oxford : Second Clarendon Press. v. 1. pp. 97-165.
Received: February 04, 2002; Revised: September 24, 2002; Accepted: May 05, 2003. 